\title{
«... for eg skal ha eit godt lag»: Friluftslivslærarar si organisering av klassen på tur
}

\author{
Inger Margrethe Tronstad ${ }^{\star}$ og Idar Kristian Lyngstad \\ Nord universitet, Norge
}

\begin{abstract}
Sammendrag
Denne artikkelen viser resultat frå ein kvalitativ studie om kva friluftslivslærarar er opptekne av og seier dei gjer, når dei organiserer klassen på friluftslivstur. Studien er gjort i norske vidaregåande skolar og folkehøgskolar, i klassar som har friluftsliv som sitt hovudfag. Data er innhenta gjennom semistrukturerte intervju med 18 friluftslivslærarar. Dataanalysen er gjort innanfor vitskaps- og kunnskapsteoretiske rammer som Alvesson \& Sköldberg (2017) og Kvale og Brinkmann (2015) skildrar for hermeneutisk analyse av intervjudata. Resultata viser at lærarane er opptekne av og brukar symbol, ritual og system for teltlag, turleiarskap, forflytting, tid, klokke og mobil. Dei gier avklaringar med elevane og er opptekne av dialog og god samtale med alle elevane i klassane. Den gode samtalen er gjennomgåande i praksisen. Analysen viser også at lærarar bruker konfliktperiodar til å betre klassemiljøet. Analysen får fram organisatoriske nøklar for at fellesskapet skal fungere i klassen og for at elevane skal nå faglege og sosiale mål i friluftsliv. Analysen viser at organisering er eit teknisk-pedagogisk, men samtidig verdilada omgrep, noko som blir drøfta i studien.
\end{abstract}

Nøkkelord: friluftslivslerar; organisering; struktur; fellesskap

\section{Abstract \\ "... Because I want to have a good team»: How Friluftsliv teachers organize the class on multi-day ski tours and overnight treks}

This article shows the results of a qualitative study of what friluftsliv teachers are interested in and says they do when they organize the class on multi-day ski tours and overnight treks. The study was conducted in Norwegian upper secondary and folk high schools, in classes with outdoor life as their main subject. Data were obtained through semi-structured interviews with 18 friluftsliv teachers. The data analysis is done within the science and epistemological theory framework that Alvesson \& Sköldberg (2017) and Kvale and Brinkmann (2015) describe for hermeneutic analysis of interview data. The results show that the teachers are preoccupied with using symbols, rituals, and systems for tent teams, tour leadership, relocation, time, clock, and mobile. They make clarifications with the students and are engaged in a dialogue with all the students in the classes. Good conversation is consistent in practice. The analysis also shows that teachers use conflict periods to improve the group environment. The study reveals organizational keys needed to

^Korrespondanse: Inger Margrethe Tronstad, e-post: inger.m.tronstad@nord.no

(C) 2022 I. M. Tronstad \& I. K. Lyngstad. This is an Open Access article distributed under the terms of the Creative Commons Attribution 4.0 International License (https://creativecommons.org/licenses/BY/4.0/), allowing third parties to copy and redistribute the material in any medium or format and to remix, transform, and build upon the material for any purpose, even commercially, provided the original work is properly cited and states its license.

Citation: I. M. Tronstad E I. K. Lyngstad. «"... for eg skal ha eit godt lag»: Friluftslivslcerarar si organisering av klassen på tur» fournal for Research in Arts and Sports Education, Special issue: Friluftsliv, dannelse, laring og didaktikk, Vol. 6(1), 2022, pp. 4-20. 
make the class function in the best possible way, and for the students to achieve academic and social goals in friluftsliv. The analysis shows that organization is a technical-pedagogical term, but at the same time, a concept that shows values the teacher has, something that is discussed in the study.

\section{Keywords: friluftsliv teacher; organization; structure; unity}

Received: March, 2021; Approved: November, 2021; Published: January, 2022

\section{Innleiing}

Kvar friluftslivsklasse på tur er situert i ein kontekst som er ei kompleks blanding av organisasjon og kulturelt og sosialt miljø (Ringer, 2002). Å studere friluftslivsklassar på tur er studiar av små komplekse, dynamiske og sosiale system. Friluftslivslæraren er ein integrert del av dette systemet og leiaren av det. I norsk vidaregåande skole og folkehøgskole er det ein del lærarar som underviser i friluftsliv som hovuddel av lærarstillinga si. Vi kallar desse friluftslivslærarar i vår studie. I norsk folkehøgskole går rundt $1100^{1}$ elevar på friluftslivslinjer årleg, i tillegg kjem friluftsliv som valbar fordjupingsretning på utdanningsprogram i vidaregåande skole, som «breiddeidrett» på idrettsfag og på naturbrukslinjer på landbruksskolar, der skolane har tilpassa lokale læreplanar og kallar dette friluftslivslinjer. Friluftslivsturar i vidaregåande og folkehøgskole er varierte når det gjeld type og lengde, og læraren si organisering vil vere ulik til dømes på segltur, vandretur, klatretur, kitetur eller skitur. Organisering og klasseleiing har likevel fellestrekk som handlar om korleis lærarar går inn i klassefellesskapet og styrer den faglege og sosiale utviklinga hos enkelteleven (Michelet, 2020). Organisering på friluftslivsturar handlar om strukturar og system læraren brukar for at klassen skal ha eit fellesskap som fungerer. Organiseringsmåtane formidlar og verdiar i opplæringa, som toleranse og likeverd (Tordsson, 2014). Klassen er i lag med læraren over tid i naturen, dei lagar eit slags lukka system. Læraren og klassen må klare seg med hjelpemidla som er med, og improvisere når problem oppstår. Læraren og elevane utfører same praktiske aktivitet på turane, og er ofte turdeltakarar på linje med kvarandre; dei går dei same oppoverbakkane, dei står i den same vinden, utfordringar løysast i lag. Læraren har likevel eit anna fokus og ansvar enn elevane. Læraren har eit hovudansvar på turane, og for at læringsprosessar blir skapt mot både faglege og sosiale mål for elevane. Det krev også organisering å få klassen til å bevege seg framover i same retning i ein fart slik at alle kjem fram.

\footnotetext{
${ }^{1}$ November 2020: 848 elever går på linjer kategorisert som friluftslivsfag, rundt 200 på liknande fag, helse, idrettsfag 1503. To skolar kan ha koda relativt like linjer ulikt, ei skidominert linje på ein skole bli plassert i Vinteridrett mens ein annan skole brukar Friluftslivsfag. Skoleåret 2018/19 gjekk det 7700 personar på folkehøgskole i Norge. Det er 148 linjer i kategorien friluftsliv, fordelt på 52 skolar. Blir idrett og ekstremsport rekna inn, er det 261 linjer, og utgjorde halvparten av elevmassen i folkehøgskolane (Aasheim, folkehøgskolekontoret, personleg kommunikasjon 2020).
} 


\section{M. Tronstad E I. K. Lyngstad}

Korleis ser det nasjonale friluftslivspedagogiske forskingsfeltet ut med tanke på organisering av klassar på friluftslivsturar? Organisering på turar med overnattingar undervegs blir drøfta i fagbøker forfatta av Horgen (2010) og Tordsson (2014), men er i mindre grad sett på i fagfellevurderte, vitskapelege publikasjonar. Horgen (2010) gir praktiske råd om korleis vinterturar i fjellet kan organiserast. Tordsson (2014) skriv om korleis organisering inneheld ein skjult læreplan: Måten undervisning blir gjort på, har sterkare bodskap enn det læraren verbalt seier. Tordsson (2014) hevdar at friluftsliv kan gi unike læringsprosessar der skjult og open læreplan kan bli samsvarande. Både Tordsson og Horgen har erfaringspedagogisk synsvinkel. Vikene et al.(2016) har i ein artikkel samla teori om leiarrolla på tur som viser leiarskap der deltakaren er delaktig og medansvarleg. Vikene et al. rettar seg inn mot vaksne, og drøftar ikkje spesifikt mot skoleelevar og ungdom. Tordsson (2014, s. 278) har tidlegare etterlyst empirisk forsking på det friluftslivspedagogiske området, mellom anna på praktisk-pedagogiske metodar.

Det har kome studiar som fokuserer korleis friluftslivslærarar arbeider med sikkerheit i vidaregåande skole (Dahl et al., 2016, 2017, 2019). Denne forskinga har gitt nyttige funn for studien vår, blant anna ved at sikkerheit handlar om struktur og kontroll under friluftslivsaktiviteten. Anna forsking ser på korleis friluftsliv i kroppsøvingsfaget i vidaregåande skole kan gi livsmeistring (Leirhaug et al., 2020), og korleis elevar erfarer sosialt fellesskap på turar med friluftslivsklassar (Lyngstad \& Sæther, 2020) Lyngstad og Sæther drøftar naturoppleving, fellesskap og demokratiforståing som ein dimensjon i omgrepet "friluftsliv literacy», og er opptekne av korleis friluftslivsturar i vidaregåande skole fremmer fellesskap og respekt for kvarandre. Ein tilgrensande profesjon som kroppsøvingslærarar har fått mange studiar om organisering og leiing, for eksempel om samarbeidslæring (Bjørke, 2020) og relasjonar mellom lærar og elev (Lagestad et al., 2019, Lyngstad et al., 2019). Bachman (2010) har undersøkt friluftslivets plass i den svenske kroppsøvinga, og fann at posisjonen til friluftsliv i faget er relativt stemoderleg. Slike studiar har overføringsverdi til studien vår, men friluftslivslærarrolla har også profesjonsspesifikke utfordringar som ikkje blir berørt der. Jordet (2007) har i ei doktorgradsavhandling drøfta nærmiljøet som klasserom og med dette erfaringspedagogiske fallgruver og fordelar, som kan ha noko overføringsverdi til studien vår, som handlar om eldre skoleungdom.

Om ein ser på internasjonal forsking, kan forskingsfelta outdoor education (OE) og outdoor adventure education (OAE) bidra med kunnskap om organisering på friluftslivsturar. OE-feltet bidreg med kunnskap om organisert undervisning i naturen med barn og unge. OAE-feltet bidreg med blant anna kunnskap om sjølvutvikling. Forskingsbidraga har avgrensa nytte for studien vår, og blir ikkje dratt mykje inn i artikkelen. Teorien til Priest og Chase (1989), conditional outdoor leadership theory (COLT), set lys på samanhengen mellom leiarskap, gruppe og situasjon. Priest og Chase (1989), seinare Priest og Gass (1997), brukar gruppeutviklingsteorien til Tuckman og Jensen (1977) som grunnlag og foreslår ulike leiarskapsstilar som kan fungere i dei ulike utviklingsfasane til ei gruppe. Det er relevant for 
studien: Friluftslivsklassar si utvikling over tid vil påverke organiseringsformene og fellesskapet.

Kunnskapstilfanget på forskingsfeltet er relativt lite. Spesifikt manglar studiar som ser på læraren si praktiske organisering av friluftslivsklassar. Studien vår ser spesielt på lengre vandreturar og skiturar med overnattingar. Problemstillinga er: Kva er friluftslivslcerarar opptekne av og seier at dei gjer når dei skal organisere klassen for å få det sosiale fellesskapet til å fungere på slike turar, og for at elevane skal nå faglege og sosiale mål?

Studien handlar spesielt om omgrepa fellesskap og organisering på friluftslivsturar, og dei blir kort forklart i dei neste delane.

\section{Fellesskap}

Omgrepet fellesskap peiker mot eit sosialt «vi», som inkluderer samhald og å høyre til ei gruppe på friluftslivstur. Eit fellesskap er generelt ein samanheng mellom eigne subjektive opplevingar, intersubjektive relasjonar og strukturar vi samhandlar i (Tjora, 2018, s. 16). Å vere avhengig av andre for å overleve barske omstende på friluftslivsturar kan forsterke fellesskapet (Tordsson, 2014). Bischoff (1995) kallar fellesskapet på tur eit funksjonsfellesskap. Elevane må bidra for kvarandre, ei anna form for fellesskap enn det ungdom har når dei til dømes går på kino. Fellesskapet på tur er eit arbeidsfellesskap og eit særskilt sosialt fellesskap, og ikkje eit konsumfellesskap, som fellesskapet på kino kan kallast.

Fellesskapet på overnattingsturar i friluftsliv heng saman med korleis læraren forstår og arbeider med gruppeprosessar på turane. Fellesskap blir konstruert gjennom ei felles forståing mellom gruppedeltakarane om at gruppa har eit felles mål, at deltakarane i gruppa er gjensidig avhengige av kvarandre og er trygge på kvarandre (Ringer, 2002, s. 194). Det finst teoriar som seier at ei gruppe gjennomgår ulike fasar i si utvikling mot eit godt fellesskap. Tuckman og Jensen (1977) kallar den første fasen «forming», medan Schutz (1989) omtalar denne som tilhøyrsfasen. Denne fasen kan vi også kalle bli-kjent-fasen. Teoriane til Tuckman og Jensen (1977) og Schutz (1989) skildrar begge ein konfliktfase, Schutz (1989) hevdar at fellesskapet blir sterkare når konfliktfasen er gjennomlevd, Schutz kallar det "samhøyrsfasen». Deltakarane opplever samhald og å høyre til gruppa. Dette kan samtidig tolkast som at det må ein konfliktfase til for å få fellesskapet til å fungere godt. Dette har vi ikkje funne utdjupa og problematisert i friluftslivsforsking, ut over Priest og Gass (1997) si kopling av outdoor leadership mot Tuckman og Jensen (1977) sin teori, der gruppa blir meir høgtpresterande etter konfliktfasen.

\section{Organisering}

Tordsson (2014) skriv at i friluftsliv skjer læring og utvikling på mange plan samtidig. Om ein ser historisk på det, var friluftslivspedagogikken frå seint 1960-tal problemorientert (Faarlund, 2005). Den friluftslivspedagogiske praksisen la til rette for ei 


\section{M. Tronstad \& I. K. Lyngstad}

erfaringsbasert, situasjonsbestemt læring. Faarlund tydeleggjorde samtidig ei verdilading av organiseringsmåtar på friluftslivsturar ved å ta i bruk symbol. Å stå i ring under samlingar med turdeltakarane, der ein gir beskjedar og snakkar i lag, er døme på symbolbruk. Ringen, kretsen, som Faarlund kalla det, har verdiar i seg om fellesskap; å stå skulder ved skulder. Kretsen vart symbol på likeverd og menneskeverd i gruppa. Eit anna døme på eit verdilada omgrep er ferdråd (Leirhaug et al., 2019). I ferdråd/kveldssamling samlast gruppa i ein ring. Ferdrådet har mange verdiar som er like med dei kretsen formidlar.

God organisering og rutinar er viktig for at grupper generelt fungerer godt. Utrygge elevar lener seg på læraren i større grad (Stensaasen \& Sletta, 2008). Gode strukturar leier elevar som ikkje er modne nok til å skjøne alle konsekvensar (Elvèn, 2010). Kva leiaren gjer, seier og meiner om til dømes værforholda på friluftslivsturar, blir sterkare for deltakarane når desse forholda er usikre. Struktur og rutinar er spesielt viktig for gruppedeltakarane som lett kan kjenne på frykt, spenning og angst når situasjonar blir tilspissa (Stensaasen \& Sletta, 2008).

Friluftslivsturar inneheld mange komplekse situasjonar. Turar er ikkje-lineære, organiske forløp; den eine turen er aldri heilt lik den andre. Friluftslivslæraren handterer relativt opne oppgåver. Improvisasjon er ein vesentleg ferdigheit for den som skal leie grupper på tur (Tordsson, 2014). Improvisasjon skjer på basis av strukturar og innanfor rammer (Oddane, 2015).

Organisering inneheld verdiar som menneskesyn og syn på samspel. Organiseringa kan fasilitere læringsprosessar slik at eleven kan kjenne på kva fellesskap i friluftsliv er. Strukturar er nødvendige for å leie og gjennomføre turar, og samtidig gir struktur grunnlag for improvisasjon undervegs.

\section{Metode}

Studien har eit eksplorativt design og plasserer seg epistemologisk innanfor eit syn som er oppteken av meining og erfaring hos personar i forskingsfeltet forskaren går inn i (Cohen et al., 2018). Forskarrolla er nært knytt til forskingstilnærminga. Det er samanheng mellom det teoretiske grunnlaget for studien, spørsmåla som blir stilt, metoden som blir vald og måten materialet blir samla inn, analysert og tolka (Maxwell, 2012). Førsteforfattar har rekruttert informantar og gjort datainnsamling. Førsteforfattar er nær forskingsfeltet gjennom tidlegare arbeid som folkehøgskolelærar. A studere og forstå noko nytt i eit forskingsfelt tar alltid utgangspunkt i ei førforståing (Kvale \& Brinkmann, 2015). Samtidig er verkelegheita for andre friluftslivslærarar annleis enn førsteforfattar si verkelegheit som friluftslivslærar. Dei har andre arbeidsgivarar, andre rammer for undervisninga og anna faginnretning i friluftsliv, dei har anna biografi og alder. Førsteforfattar sin kunnskap om lærararbeid i friluftsliv kan vere ein styrke i kommunikasjonen med informantane, men samtidig vere ei ulempe om førsteforfattar blir for nært data i analyseprosessen. 


\section{Rekruttering av informantar og datainnsamling}

Data er innhenta gjennom semistrukturerte intervju med eit utval friluftslivslærarar. Lærarane var strategisk utvald med tanke på problemstillinga i studien (Kvale \& Brinkmann, 2015). Utvalskriterier var at lærarane skulle ha fleire års undervisningserfaring i friluftsliv, og være frå begge skoleslaga; vidaregåande og folkehøgskole. Utvalet vart rimeleg jamt fordelt mellom kjønn, skoleslag og erfaringsbakgrunn. På grunn av at informantane ikkje skal kjenne igjen kvarandre i materialet, valde førsteforfattar å ikkje intervjue fleire enn to frå same skole. Dette gjer at fleire som kunne gitt gode intervju ikkje er med i undersøkinga. Datamaterialet er rikt, likevel har studien gått glipp av potensielt rike utsegn i dette etiske valet.

Friluftslivslærarane vart kontakta ved e-post. Av 20 som vart kontakta, svara 18 ja til å bli med. Dei som ikkje svara ja, gav til grunn at dei ikkje hadde nok friluftslivsovernattingsdøgn med elevane sine for studien. 10 friluftslivslærarar arbeida $\mathrm{i}$ folkehøgskole og 8 i vidaregåande skole på intervjutidspunktet. I utvalet var det fleire som hadde yrkeserfaring frå begge skoleslaga. Friluftslivslærarane som er sitert i artikkelen, har fått pseudonym. Brit, David, Else, Frode, Johan, Kine, Paula, Lasse og Martin arbeida i folkehøgskole. Carin, Nils, Kjartan og Ragnar var lærarar frå vidaregåande skole.

Intervjuguiden var semistrukturert og bygd opp med tema. Tema var til dømes refleksjon over eigen profesjonspraksis, praktisk kunnskap om bygging av fellesskap, sosial læring og handtering av gruppeprosessen. Konkrete spørsmål var til dømes: Korleis organiserer du dagen undervegs? Kva er det som skapar eit godt fellesskap i ein klasse? Lærarane snakka også om korleis dei organiserer klassen over heile år. Intervjuguiden var praksisnær, og skulle opplevast aktuell for friluftslivslærarane.

Intervjustrategien var at friluftslivslærarane skulle få anledning til å skildre organiseringsmåtane sine. Seks intervju vart gjort ansikt til ansikt, tolv på telefon. Dette kan vere ei svakheit med metoden. Ulik type intervjusettingar kan gi ulik intervjukvalitet. Førsteforfattar, som gjorde intervjua, opplevde ikkje at den eine intervjutypen stakk seg ut som meir informasjonsgivande enn den andre. Vurderingane av transkripsjonane tyder på det same. Telefonbaserte intervju gjorde at ein kunne invitere med friluftslivslærarar utan tanke for økonomi og tidsbruk. Slik var telefonbaserte intervju egna for formålet vårt, og fleire lærarar frå fleire skolar kunne delta. I telefonbaserte intervju missar ein kroppsspråk, men kroppsspråk er heller ikkje brukt som informasjonskjelde til verdifull data i denne undersøkinga. Intervjua vart teke opp på lydfil. Intervjua var relativt frie samtaler der intervjuar kom inn med tema og spørsmål undervegs, slik at samtalen skulle vere så naturleg som mogleg. Ein strammare intervjustrategi kunne gitt andre svar. Intervjustrategien var at informanten skulle fortelje fritt om kva ho eller han er oppteken av og gjer på friluftlivsturer når det gjelder organisering.

\section{Dataanalyse og tolking}

I dataanalysen brukte vi hermeneutiske analyseprinsipp, mellom anna eit prinsipp om å veksle mellom forståing av friluftslivslærarane sine utsegn, innsikt frå tidlegare 


\section{M. Tronstad \& I. K. Lyngstad}

forsking, teoretisk grunnlag og eiga førforståing, for å komme fram til ei tolking som hadde god substans og var logisk (Kvale \& Brinkmann, 2015). Enkeltutsegn frå friluftslivslærarane vart tolka og plassert i forhold til heilskapen i materialet. Underliggjande meining i det som friluftslivslærarane sa i intervjua vart tolka og kva det kunne bety for problemstillinga i studien. I tillegg prøvde vi å vere kritisk til tolkingar, språk og selektivitet. Vi gjennomførte ein analyse som var utan ein fastlagd statisk struktur, innanfor vitskaps- og kunnskapsteoretiske rammer som Alvesson og Sköldberg (2017) skisserer.

Undervegs i dataanalysen vart vi merksame på at lærarane meinte at struktur er sentralt for å lykkast med ei gruppe på lengre turar, og vi valde å arbeide spesielt med dette i den vidare dataanalysen.

Første del i analyseprosessen var at datamaterialet vart sortert tematisk i underkategoriane «å sjå gruppeprosessen i eigen klasse», «å bygge fellesskap», «å handtere turleiarar» og "teltlag undervegs». I den vidare analysen vaks sentrale tema frå datamaterialet fram, og det skjedde ei rekategorisering av data. Data vart rekategorisert under termar som system, symbol, ritual, avklaring og samtale (Kvale \& Brinkmann, 2015). I arbeidet med analysen vaks det fram funn som svarer på problemstillinga $i$ studien.

\section{Kvalitetsdrøfting av materialet}

Den kvalitative forskinga og det tolkande paradigmet blir ofte knytt opp mot at forskinga skal vere truverdig, påliteleg og ha overføringsverdi (Guba \& Lincoln, 1998). Fordi friluftslivslærarane var opptekne av temaet organisering, opplevde vi at problemstillinga vart opplyst med innhaldsrike utsegner og refleksjonar frå lærarane (Malterud et al., 2015). I intervjua var eit samspel mellom friluftslivslæraren og intervjuaren (Kvale \& Brinkmann, 2015). Det er vald å vise organiseringsformer som lærarane seier fungerer. I datamaterialet finst også funn som viser det motsette, og lærarar fortalde og om mislykka organiseringsformer. Denne studien undersøker kva lærarane seier dei gjer når organiseringa fungerer. Ein sjølvkritisk merknad er at studien ikkje får fram kva som kan gå gale med organiseringa, og at lærarane sine val av organiseringsmåte også kan få negativt utfall. Ein annan sjølvkritisk merknad er at organisering for å auke læringsutbytte i ferdigheiter i friluftsliv, som t.d. klatring, segling o.1., ikkje blir opplyst og drøfta i studien. Grunngjevinga for desse avgrensingane er at vi ville ha merksemda på organisering for få klassen til å fungere som eit godt lag på lengre turar, og for at elevane skal nå faglege og sosial mål.

Miljøet med friluftslivslærarar i Noreg er lite og gjennomsiktig, det skal lite til før anonymiteten forsvinn. Identitet og lokalisering er difor skrive bort i intervjua (Ryen, 2010, s. 209). Friluftslivslærarane har fått tilsendt artikkelen i etterkant og fått sagt si meining om sitat og tolkingane som er gjort. Dei som blir forska på i dette tilfellet, veit at dei blir forska på, og kva vi ser etter. Studien er godkjent av NSD - Norsk senter for forskingsdata. 


\section{Funn}

Analysen fekk fram fleire hovudfunn. Analysen viser at lærarane er opptekne av og brukar symbol og ritual. Dei er også opptekne av struktur, og brukar system for teltlag, turleiarskap, forflytting, samt for tid, klokke og mobil. Dei gjer forventningsavklaringar og andre avklaringar med elevane, og er opptekne av dialog og god samtale med elevane. Lærarane bruker dessutan konfliktfasar, som gjerne oppstår i friluftslivsklasser, til å arbeide med klassemiljøet. Funna blir vidare skildra meir inngåande, med konkrete eksempel.

\section{Symbol}

Ein av friluftslivslærarane, Frode, seier at gruppeprosessar på friluftslivsturar er ganske mykje arbeid, fordi det er viktig å ha ei god og dynamisk gruppe. Han har turar der klassen skal vere ute lenge "da er du avhengig av at du bygger gode lagspelarar, [...] for eg skal ha eit godt lag», seier han. Analysen viser at ein del av strategien i arbeidet med elevgruppene er å bruke symbol, som er lada med verdiar. Lasse fortel han tar i bruk og introduserer symbol om likeverd og fellesskap overfor elevane når dei er på tur:

Første dagen stoppar vi og så står vi skulder ved skulder. Eg seier: Eg vil at når vi står og snakkar så står vi i ein ring. No har de gått på skole i 12-15 år, og sitte ved sidan av kvarandre på rekke og rad. No skal vi stå skulder ved skulder. Vi er likeverdige. [...] Det er ingen skilnad på oss, det er berre skilnad på erfaring.

Lasse speler også på ringen rundt bålet som eit symbol på likeverd: «Vi sitt i ein ring rundt bålet. Vi sitt ikkje på rekke og rad». Han fortel alle skal ha varme frå bålet. Carin fortel om ringen som symbol. Ho samlar elevane i ring i kvar pause på turar: «Eg samlar elevane mykje i ring. Det er standaren min; 'samlast i ring', 'samlast i ring'". Ho har mykje fokus på den gode ringen overfor elevane. Ingen skal stå utanfor ringen. Else og David brukar også andre symbol. Dei fortel om symbolske kosedyr til å "hause» enkeltelevar sin innsats eller innstilling undervegs på tur. Kosedyra fungerer som ein vandrepokal som får ny eigar på kveldssamlinga. Eleven som har vandrepokalen, kan foreslå kven som skal få den neste dag. Læraren sett fokus på innsats og positiv innstilling i gruppa, og løftar fram elevar som treng å synast meir.

\section{Ritual}

Eit anna funn i analysen er bruk av ritual. Friluftslivslærarane fortel spesielt om samlingar om morgonen og kvelden som kan bli forstått som ritualiserte. Morgonsamlinga før dei går er ei ståande samling, kveldssamlinga er ei sitjande samling, fortel David. På morgonsamlinga brukar mange lærarar ritualiserte metodiske grep for å ta «tempen» på klassen. Grepa gjer det meir gjennomsiktig kven som slit, til dømes. Brit fortel: 


\section{M. Tronstad E I. K. Lyngstad}

På morgonen samlast vi i ring. Turleiarane tek ein runde på om klassen har sove godt eller ikkje. Det er noko som heiter "fist of five», der du viser på handa, der fem er best og ein, er ganske mørkt [...]. Er det kaldt: Vott. Tommel opp eller ut eller ned. «Værmelding» er ein annan versjon, da seier ein og ein litt meir.

Brit fortel også om kveldssamlinga:

Kveldssamlingane skapar noko bra i klassen. [...] Vi snakkar om dagen og leiarskapet, turleiarane dagen etter kan ta lærdom av det. [...] Vi snakkar om «I dag gjekk det veldig bra med pausane, og det var god framdrift», eller: «I dag så brukte folk veldig lang tid på å kome i gang etter pausane, kvifor var det sånn?» Eg er innom teltlaget som har vore turleiarar på førehand. [...] Det kjem fram fleire nyansar når dei får snakke i ei lita gruppe først.

Lærarar fortel at dei legg vekt på å reflektere over turerfaringar under kveldssamlingane. Læraren og elevane arbeider i lag med erfaringane frå dagen og gjer seg mentalt klare for dagen etter. Elevane har eit forum å snakke i. Ulike syn på kva som har hendt, kan gjere at elevane forstår betre, i staden for at eit argument skal vere rett og eit anna feil. Kveldssamlingane kan minke frustrasjon og auke framdrift i forhold til fysiske turmål. Kultur for refleksjon og læring blir innarbeida.

Martin opplever at kveldssamlinga skaper fellesskap. Han seier: «Bål, bålkaffe og runde, ${ }^{2}$ det er nesten tilstrekkeleg for å kome godt i gang med ei gruppe, for å skape eit fellesskap. Nokon opnar seg fort, men runden gjer at alle får sjansen.» Om eleven slit elles, er eleven $i$ alle fall med i det store fellesskapet om kvelden, kommenterer han.

\section{System}

Det peika seg tidleg ut i analysen at friluftslivslærarane var opptekne av struktur. Lærarane fortalde at dei utviklar ulike system som gir struktur i organiseringa. Systema blir brukt i ulike settingar undervegs. Lærarane seier dei bruker system for teltlag, turleiarskap, forflytting, tid, klokke og mobil. Desse systema blir skildra nedanfor i nemnde rekkefølgje.

\section{System for teltlag}

Læraren deler opp teltlaga. Teltlaga bærer fellesutstyret sitt i lag. Teltlaga bør seg imellom vere jamne når det gjeld det fysiske, sosiale og mentale mellom elevane. Nokre friluftslivslærarar har same teltlag eit halvt år, andre rullerer. Lasse seier: «Vi rullerer veldig mykje. Vi har så fargerik gruppe at vi kan ikkje ha faste teltlag. Det fungerer ikkje. Det blir sånn 'Skal eg ligge i telt med ho ...? I eit halvt år?'” Ein annan lærar, Nils, fortel om ei erfaring med oppdeling av teltlag:

\footnotetext{
${ }^{2}$ Runde er ein runde er alle må seie noko om eit bestemt tema: innbilt alder, kor mange ungar du skal ha, favorittfilm, ei god naturoppleving - for å bli betre kjent og for at ungdommane skal få lik taletid i ringen.
} 
Ein gong fekk dei skrive opp tre dei ville bu i telt med [...] det vart eit teltlag med dei verste gutane, det vart berre kaos. Alt gjekk seint, dei gjorde ikkje det dei skulle. Når dei hadde pakka ned leirplassen låg det ting igjen etter dei. Dei mista primusen sin, og fann den aldri igjen. Dei sette på ein skogbrann. Vi fekk stoppa den, da den var ti gange femti meter.

Nils legg alltid teltlagkabalen sjølv etter dette, sa han.

Friluftslivslærarane meiner ulikt om kor vidt dei skal sove i lag med elevane i telt. Mange har eige telt, andre søv med andreårselevane. Anderårselevane er elevar som får eit andre år i folkehøgskolen, der dei får leiarutfordringar. Andre meiner det er viktig å sove i lag med elevane, og støtte når det trengs. Forholdet nærleik og distanse mellom lærar og elev, regulerer læraren. Når teltlaga er bestemt, er det viktig å få samspelet i teltlaget til å fungere. Nokre friluftslivslærarar har utvikla skjema som teltlaga må snakke igjennom før tur for å vere i forkant av eventuelle konfliktar. På vidaregåande skole får elevane av og til arbeidsoppgåver tildelt dag for dag, slik at det blir utvitydig kven som skal gjere kva i teltlaget.

\section{System for turleiarskap}

Dei fleste friluftslivslærarane sett inn elevane som turleiarar, grupper med elevar som har det daglege leiarskapet. Oftast er dette teltlag, og turleiarskapet rullerer mellom teltlaga igjennom turen. Ein friluftslivslærar seier han ikkje fekk det til, elevane handterte ikkje leiarskapet på ein god måte. Kine fortel om korleis ho organiserer turleiarane: «Eg set dei inn som turleiarar allereie på hausten. [...] Alle får prøvd seg og veks veldig mykje på det [...] Eg kan gå bort til dei som les kart og spørje: «Du, korleis les du gruppa di no?»

Ved å ha turleiarar i klassen, set friluftslivslærarane fokus på leiarskap blant elevane. Leiarskapet og å sjå gruppa blir eit felles mål for alle, noko alle arbeider mot. "Elevane får eigarforhold til opplegget vi held på med», fortel David. Samtidig frigjer denne organiseringa læraren; læraren treng ikkje gå framme sjølv og orientere og kan følgje opp klassen som heilskap i større grad. Læraren blir meir medspelar og på linje med dei andre. Lærarar fortel om korleis leiarskap på denne måten hindrar opposisjon over tid frå elevane. Når elevane gir tilbakemelding til ulike turleiarar, blir det over tid sett fokus på leiarskapet som fenomen i friluftsliv, og ikkje ein bestemt leiar, som person.

Lærarar seier også at dei går rundt til telta på kveldane for ein prat. Mykje av opplæringa i turleiarskap skjer i teltrunden. På teltrunden kan læraren ta opp sårbare ting som korleis det praktiske arbeidet går i teltet og om korleis elevane taklar turleiarskapet. Her gir læraren ei tilpassa rettleiing til kvart enkelt teltlag.

\section{System under forflytting}

Fleire friluftslivslærarar brukar system som dette under forflytting: Turleiarane har ansvar for kart, kompass og orientering, og at rytmen på forflyttinga er 50 minutt gange, deretter pause i 10 minutt, gjennom dagen. Turleiarane har ansvar for 


\section{M. Tronstad E I. K. Lyngstad}

framdrifta, men alle skal vite kor dei er på kartet, for å øve seg på kart og kompass. Turleiarane øver på å gå framme og få med seg heile klassen. Teltlag der det er ein del som tek ansvar og gir klare beskjedar, blir turleiarar først, for å skapa god kultur for å leie kvarandre på turane.

Kine dempar konkurranse og fokus på fysisk form mellom elevane, og arbeider med å halde tempoet nede: «Eg ser når dei begynner å bli litt raude i ansiktet. Eg høyrer når dei sluttar å snakke. Eg prøver veldig hardt å plukke av alt som har med prestasjon og konkurranse å gjere.» Kine vil redusere utryggheit i klassen, skilnad på fysisk form er angstdrivande for enkelte. Carin fortel at klare beskjedar er viktig når klassen forflytter seg. "Det er viktig at elevane veit kva som skal møte oss framover [...]. Alt må vere soleklart. Det er viktig for å få flyt i ei gruppe.» Lasse fortel om sitt system:

Eg lagar system slik at «trøkket» blir jamt fordelt. Ting skal vere rettferdig. [...] Det er heilt utruleg korleis systemet fangar med ein gong ting blir opplevd rettferdig. Det blir ikkje konfliktar. [...] Den tyngste plassen er å gå sist. Da må du ta igjen alle luker. Den beste plassen å gå om du er sliten er å gå nummer to. Å gå heilt framme i gruppa. Det er viktig å ha dei dårlegaste der.

\section{System for tid, klokke og mobil}

Lærarane praktiserer system for tid, klokke og mobil. Carin seier «Dei skal ha eit enkelt armbandsur på armen på tur.» Ho gjer det for å få flyt i gruppa og for å halde tida. Carin har 16-åringar i vidaregåande skole. David har folkehøgskoleelevar på 19-20 år, og ei anna meining om klokkebruken. Han fortel om ei utvikling der dei sluttar å bruke klokke på turane mot slutten av skoleåret:

På starten av skoleåret brukar vi klokke og prøver å halde 50:10 [...]. Utover i skoleåret prøver vi å gjere ganske mykje utan tid. [...] Da blir det på «gefühlen» å gå ein time og ha pause i cirka 10 minutt [...] Elevane likar det veldig godt, når dei kjem over det første sjokket. [...] Dei siste åra har elevane vore veldig på at dei ikkje vil vite noko om kva klokka er før vi er tilbake til folk. Dei vil vere heilt avskore frå samfunnet. [...] Vi skal bevege oss eit dagsverk, også skal vi slå leir.

David meiner at «klokkelaust samfunn» fungerer når gruppa er godt innkøyrd, og klassen kan rutinane og strukturane. Han kallar det ei «avrusing frå skjerm og hektisk kvardag». Vala til David og Carin er ein del av ein større diskusjon om bruk av mobil på tur. Mobil engasjerer friluftslivslærarane. Frode seier: «Eg har ei stor utfordring, og det er 4G. Eg kan ikkje fordra det. Det tek så mykje tid. Dei fjernar seg. Det synest eg er jækla utfordrande.» Friluftslivslærarane ønsker ikkje mobilen framme, men dei ser den gir reklame for friluftslivslinja, elevane legg ut bilde på sosiale media. Fleire har mobilfrie turar, eller at mobilen kun skal opp i soveposen, utan lyd, på kvelden.

\section{Avklaring og samtale}

I organiseringa av klassen er også verbal kommunikasjon sentral. Leiarstil varierer etter situasjonane, men den verbale kommunikasjonen har særtrekk som kan delast 
opp mellom avklaringar og samtalar. Vidare presenterer vi dømer på forventningsavklaringar, føringar og samtaler.

Paula fortel om kva ho legg vekt på i den første turen med ein klasse: «Eg snakkar med dei om korleis vi skal ha det i klassen. At vi er ei gruppe og vi tek vare på kvarandre. [...] Vi har ord for kvelden kvar kveld der ein gir av seg sjølv og fortel ting som ger at det blir meir openheit i klassen der alle blir inkludert.» Leikar blir brukt til å bryte isen mellom elevane slik at relasjonane kan byggast.

Johan har forventningsavklaringar med klassane sine som oftast munnar ut i: «Du må vere eit menneske som ein gjerne vil dra på tur i lag med. Det seier mykje om ein person. Det blir det mykje diskusjonar i klassen, i forhold til korleis folk oppfører seg, og kva ein seier.» Carin fortel korleis ho arbeider for å få fram det gode i gruppa: «Tett dialog og mykje leik. Og føring, vi legg klar føring. Brukar lang tid på å få fram ulike folk.» Med å få fram ulike folk meiner Carin å løfte fram elevar som treng å synest meir. Carin seier ho gir klare føringar, ein type avklaring. Vi har nemnt tidlegare at Kine "plukkar av» prestasjon og konkurranse. Lærarane observerer gruppa og går inn og legg føringar for korleis situasjonane skal utarte seg.

Friluftslivslærarar i studien fortel at samtalar mellom lærar og elev ofte skjer samtidig som dei utfører same type fysisk arbeid. Ragnar seier: "Friluftslivslærarar er mykje nærmare på kompis-skalaen.» Kine seier: «Ein må vere på i situasjonane. Det handlar mykje om kontekst.» Nils fortel at samtalen er nær, leiken og har flat struktur. Friluftslivslærarane får mange samtalepunkt med kvar enkelt elev, i teltrundar og samlingar, undervegs i vandring og aktivitet.

\section{Konfliktfasar blir brukt til å betre klassemiljøet}

Fleire av friluftslivslærarane fortel om at det oppstår konfliktar i friluftslivsklassane på eitt eller anna tidspunkt i skoleåret. Johan fortel:

Til å begynne med legg elevane lokk på alt. Det er som å gå guida turar på ei veke [...] alle smiler og er hyggelege [...] På folkehøgskole går ikkje det. Personlegdommane kjem fram på eit tidspunkt. [...] så smell det, når dei tinga dei ikkje kan fordra kjem fram, og folk er slitne og sultne [...] Om det tappar for energi å vere i lag [...], da er langtur heilt drepen å vere med på [...]. Difor er det viktig å få det sosiale til å fungere.

Kjartan fortel: «Elevane er i ein klasse som dei ikkje har valt sjølv. Dei går på skole og må fullføre. Så får dei utfordringar med kvarandre, [...]. Du må ta det alvorleg, og lære dei å prate saman.» Nokre lærarar opplever at konfliktane kjem på bestemte turar. Lærarane brukar konfliktfasen aktivt i gruppeprosessen for å betre klassemiljøet. Det er gunstig å få konfliktane ganske tidleg i hausthalvåret, fleire lærarar legg turar slik at konfliktfasen kan kome da. Da får klassen tid til å «sette seg» mot haustferien, seier fleire av lærarane. Paula seier: «Eg brukar å vente på turen der det smell, for da blir klassen mykje betre etterpå.» 


\section{M. Tronstad E I. K. Lyngstad}

\section{Drøfting}

Analysen viser at organisering er eit teknisk-pedagogisk omgrep, som samtidig er verdilada. Lærarane er opptekne av og bruker symbol og ritual, som reflekterer verdiar læraren ønskjer at elevane skal fange opp og forstå. Symbola skulder ved skulder, alle skal få varme frå bålet, ingen utanfor, er lada med bestemte verdiar, og formidlar fellesskap og likeverd. Morgon- og kveldssamlingane er ritualiserte, og dei får fram verdiar som lik taletid, betydninga av refleksjon i fellesskap og respekt og omsorg for kvarandre. Det er bodskap i forma, og det verbalt uttala. Desse funna kan knytast til Lyngstad og Sæther sin studie (2019) og deira funn om korleis fellesskapsfølelse og demokratiforståing blir fremja på friluftslivsturar i vidaregåande skole. Lyngstad og Sæther peikar på korleis diskusjon og talemåtar til kvarandre er viktige ferdigheiter på turar og grunnleggiande for forståing av demokratiske prinsipp. Studien vår viser at praksis samsvarar med teori om formidling av verdiar i friluftsliv (Tordsson, 2014), og at organisering frå læraren synleggjer bestemte verdiar for elevane. Studien viser at lærarane arbeider systematisk med å formidle verdiar gjennom organiseringsmåtar.

Eit døme på korleis verdiar formidlast gjennom organiseringsmåtar, er analysen som viser at ritualiserte og symbolske organiseringsmåtar blir innført frå første møte med elevane. Tidleg i gruppeprosessen er det enklast for læraren å få inn kva strukturar som gjeld og formidle bestemte verdiar gjennom organiseringsmåtar, ifølgje utsegn om mellom anna at ringen blir brukt tidleg i friluftslivsklassar. Dette funnet er i tråd med gruppeprosessteori, som seier at best grobotn for å påverke er tidleg i starten av gruppeprosessar (Tuckman \& Jensen, 1977). Tuckman og Jensen kallar den første fasen i gruppeprosessar for "forming», og analysen vår viser at lærarar er opptekne av å få inn gode vaner i elevgruppa og forme dei, mellom anna ved bruk av ringen og ritualiserte morgon- og kveldssamlingar. Funna i studien føyer seg inn i litteraturen om symbol spesielt, som Faarlund (2005) og Leirhaug et al. (2019) har forfatta. Samtidig utdjupar studien vår verdiladninga i symbola. Studien viser at friluftslivslærarar flettar inn fleire verdiar samtidig i organiseringa; verdiar om sosialt fellesskap, respekt for kvarandre og likeverd. Friluftslivslærarane formidlar verdiar giennom symbol og i morgon- og kveldssamlingar, og dei seier at elevane fangar verdiar som ligg innbakt i symbol og måten samlingane blir gjennomført på.

Analysen viser i tillegg at spesielt kveldssamlingane blir dyrka fram av friluftslivslærar i lag med elevane som eit positivt innslag på friluftslivsturane. Dette funnet utdjupar det Horgen (2010) skriv om kveldssamlingar på friluftslivsturar vinterstid, ved at lærarar og elever utviklar innhaldet i kveldssamlingar i fellesskap. Lærarar i studien vår fortel om verdiar om fellesskap på tur og elles korleis verdiar i livet blir drøfta under kveldssamlingar. Funna våre viser også at kveldssamlingar kan ha eit større sosialt fokus enn eit ferdråd (Faarlund, 2005). Kveldssamlingane blir hegna om og utvikla for å bygge fellesskapet i klassen, men også for å fremje personleg utvikling hos kvar elev. 
Funna i studien hjelper til å utdjupe kva det vil seie å ha med ungdommar på friluftslivsturar i vidaregåande skole og folkehøgskole. Kveldssamling, andre ritual og bruk av symbol ser ut til å vere systematisert og gjort bevist av friluftslivslærarane, meir enn det vi finn skildra i friluftslivspedagogisk fag- og forskingslitteratur. Fagbøker har ofte vaksenorientert fokus, og manglar fokus på skoleungdom, som vi har nemnt. Skoleungdom har ei anna modning enn vaksne, som forfattarar av fagbøker (Horgen, 2010; Tordsson, 2014; Vikene et al., 2016) skriv meir om. Det har følger for den pedagogiske tilnærminga. Skilnaden kan også vere at friluftslivslærarane i studien vår har kontakt med elevane over mykje tid. Dette kan skape tydelegare mønster med bruk av symbol og ritualisert praksis på friluftslivsturar. Ein kan tenke seg at ritual vil vekse fram hos grupper som er på såpass mange turar i lag.

Friluftslivslærarane i studien vår skildrar organiseringsmåtar for å nå friluftslivsfaglege og sosiale mål. Elevane får posisjonar dei kan klare, der dei kan vere rollemodellar for kvarandre. Systema gir ramme for friluftslivsfagleg læring: elevane orienterer, vurderer pauseplassar og leirplassar, vær og vind. Strukturen bidrar til å nå sosiale mål: Elevane tar leiarskap, hever stemma og tar avgjerder, og må tole motbør om ikkje alle er einige. Elevane må lese gruppa og ta vurderingar. Det faglege og sosiale er vevd inn i kvarandre, i reelle situasjonar.

Studien utdjupar også korleis friluftslivslærarar praktiserer erfaringspedagogikk (Faarlund, 2005) som er tilpassa elevane sine. Dei sentrale stikkorda er fast struktur over tid, og system som legg til rette for erfaringslæring. Funna seier noko om friluftslivslæraren sin nærleik til elevane og kontinuerlege arbeid med klassen gjennom turar som følger etter kvarandre, gjennom heile skoleår. Funna samsvarer mykje med den problembaserte undervisningsforma som friluftslivspedagogisk litteratur har forfekta (Faarlund, 2005), og viser ei konstruktiv elevsentrering i pedagogikken (Jordet, 2007). Strukturane er strammare enn erfaringspedagogikk som er skildra hos til dømes Horgen (2010), Tordsson (2014) og Vikene et al. (2016). Skildringane deira fangar ikkje opp så tydeleg skoleungdom sitt behov for struktur, skoleungdom sitt utviklingsnivå, og behov for tryggleik undervegs. Lærarane i denne studien legg vekt på det, med stor tyngde.

Analysen viser i tillegg at strukturane er faste nok til å gi tryggleik, og dynamiske nok til å improvisere. Dette er i tråd med Oddane (2015), som poengterer at god struktur er ein føresetnad for god improvisasjon. Friluftslivslærarane styrer sikkerheit med struktur og rammer, noko som relaterer seg til forskinga til Dahl et al. (2017), som viser korleis friluftslivslærarar regulerer risiko med organisering av nivåtilpassing av turane.

Med struktur blir rytmen på dagen avklara, det frigjer energi til fokus på andre læringsmål. Elevane blir mindre usikre, ei trygging som er viktig (Stensaasen \& Sletta, 2008). Strukturen gir premiss for korleis turen skjer og korleis elevane er med og bestemmer. Friluftslivslærarane har mål om at elevane skal bli sjølvgåande, klare seg sjølv på tur, og ein sjølvgåande klasse fremmer den utviklinga. Fellesskapet 


\section{M. Tronstad \& I. K. Lyngstad}

er tydeleg med på å skape den individuelle utviklinga. Friluftslivslærarane i studien prøver å få maksimalt ut av elevføresetnadene, med informasjon, samtalar og struktur. Avklaringane skjer ved handling, føring, samtaler og jamn informasjonsflyt. Samtalen med elevane er eit viktig verktøy for å få til organiseringa, og i friluftslivsfaget har ofte samtalen god plass, på grunn av tida læraren har med elevane sine.

Friluftslivslærarane i studien har fokus på gruppeprosessane gjennom heile året, og elevane lærer leiing av grupper. Friluftslivslærarane veit at konfliktar i elevgrupper vil kome. Ein konfliktfase i elevgruppa er gunstig å få i haustsemesteret, seier nokre av lærarane. Funn om konfliktar frå studien er i tråd med Schutz sin (1989) gruppeutviklingsteori og viser korleis lærarane er medvitne om og brukar konfliktar konstruktivt. Organiseringa gjennom året har ei innebygd konfliktforståing hos friluftslivslærarane, som kan sjåast i samanheng med Schutz (1989) sin teori om konfliktfasen i gruppeutvikling. Etter ein konfliktfase blir klassen reetablert i det Schutz kallar samhøyrsfasen. Organiseringa må fungere slik at konfliktfasen blir handterbar. Fellesskapet blir konstruert gjennom ei delt forståing av å ha felles mål, vere gjensidig avhengige av kvarandre og vere trygge (Ringer, 2002, s. 194). Funna viser til sist at organiseringa kan munne ut i eit større fellesskap, ei oppleving av samhald, å høyre til, vennskap og sosial kompetanse.

\section{Konklusjon}

Studien viser kva utvalde lærarar er opptekne av og seier dei gjer når dei organiserer friluftslivsklasser på turar. Dei sentrale funna i studien er at lærarar er opptekne av og brukar symbol, ritual og system for teltlag, turleiarskap, forflytting, tid, klokke og mobil. Dei gjer avklaringar og er opptekne av dialog og god samtale med alle elevane i klassen. Hovudfunna kan vere nøklar til å forstå særskilte trekk ved organiseringa til friluftslivslærarane på friluftslivsturar.

Studien viser at omgrepet organisering er teknisk-pedagogisk, men samtidig eit verdilada omgrep som blir brukt bevisst av lærarar for å få fram fagleg og sosial utvikling hos eleven. Friluftslivslærarane praktiserer jamn samtaleflyt mellom lærar og elev. Friluftslivslærarane i studien har elevane minst eit år. Tida gjer noko med korleis dei ser klassen og utviklinga av den.

Studien bidrar til at kunnskapen aukar om organiseringsmåtar på friluftlivsturar som gir positive resultat. Feltet vil likevel aldri ha ein fasit. Studien viser system friluftslivslærarar brukar som fungerer for dei. Det kan vere eit utgangspunkt for lærarar og utdjupande forsking. Lærarane legg stor vekt på at klassen skal fungere ilag. Friluftslivslærarane veit konfliktperiodar kjem. Denne forventninga om konfliktar er baka inn i organiseringa, slik at klassen kan arbeide seg igjennom konfliktfasar for å styrke fellesskapet. Studien viser at fellesskap har eit overordna fokus i organisering av friluftslivsklassar. 


\section{Forfattarinformasjon}

Inger Margrethe Tronstad, stipendiat ved Nord universitet, Fakultet for lærerutdanning, kunst og kultur. Ho har arbeida som lærar i folkehøgskole, vidaregåande og barne- og ungdomskole i 20 år. Ho er i gang med ei doktorgradsavhandling om profesjonskunnskap om friluftslivslærarar.

Idar Kristian Lyngstad, professor ved Nord universitet, Fakultet for lærerutdanning, kunst og kultur. Han har publisert studiar med hovudtyngde i kroppsøving, men no i seinare tid også om friluftliv.

\section{Referansar}

Alvesson, M. \& Sköldberg, K. (2017). Tolkning og reflektion. Vetenskapsfilisofi och kvalitativ metod (3. utg.). Studentlitteratur.

Backman, E. (2010). Friluftsliv $i$ Swedish Physical Education - a struggle of values. Educational and sociological perspectives [Doktorgradsavhandling, Stockholms universitet]. DiVA. http://urn.kb.se/resolve?urn=urn: nbn:se:su:diva-38238

Bischoff, A. (1995). Friluftsliv og behandling-brugen av friluftsliv, idrcet og mentaltrening af kvinder med kroniske muskelsmerter [Upublisert notat]. Høgskolen i Telemark.

Bjørke, L. (2020). Utfordringene og kompleksiteten ved pedagogisk endring: En undersøkelse av lareres og elevers erfaringer fra implementering av samarbeidslaring $i$ kroppsøving [Doktorgradsavhandling, Høgskolen i Innlandet]. https://hdl.handle.net/11250/2688751

Cohen, L., Manion, L. \& Morrison, K. (2018). Research methods in education (8. utg.). Routledge.

Dahl, L., Lynch, P., Moe, V. F. \& Aadland, E. (2016). Accidents in Norwegian secondary school friluftsliv: Implications for teacher and student competence. Fournal of Adventure Education and Outdoor Learning, 16(3), 222-238. https://doi.org/10.1080/14729679.2015.1122542

Dahl, L., Moe, V. F. \& Standal, Ø. F. (2017). På tur med det uforutsette: Refleksjoner om sikkerhet hos friluftslivslærere på videregående skole. Nordic Studies in Education, 37(3-4), 201-216. https://doi.org/ 10.18261/issn1891-5949-2017-03-04-06

Dahl, L., Standal, Ø. F. \& Moe, V. F. (2019). Norwegian teachers' safety strategies for Friluftsliv excursions: Implications for inclusive education. Fournal of Adventure Education and Outdoor Learning, 19(3), $256-268$. https://doi.org/10.1080/14729679.2018.1525415

Faarlund, N. (2005, 1. oktober). Vegledning [sic] eller situasjonsorientert læring og dannelsen av militære ledere. Pacem tidsskrift for militcer etikk. http://pacem.no/2005/vegledning-eller-situasjonsorientert-laeringog-dannelsen-av-militaere-ledere/

Guba, E. G. \& Lincoln, Y. S. (1989). Fourth generation evaluation. Sage.

Horgen, A. (2009). Friluftslivsveiledning vinterstid. Cappelen Damm.

Jordet, A. N. (2007). Ncermiljøet som klasserom. En undersøkelse om uteskolens didaktikk $i$ et danningsteoretisk og erfaringspedagogisk perspektiv [Dokorgradsavhandling, Universitetet i Oslo]. http://hdl.handle.net/11250/132008

Kvale, S. \& Brinkman, S. (2015). Det kvalitative forskningsintervju (3. utg). Gyldendal Norsk Forlag.

Lagestad, P., Lyngstad, I., Bjerke, Ø. \& Ropo, E. (2019). High school students' experiences of being 'seen' by their physical education teachers. Sport, Education and Society 25(2), 173-184. https://doi.org/10.1080/ 13573322.2019.1567485

Leirhaug, P. E., Grøteide, H., Høyem, H. \& Abelsen, K. (2020). Naturopplevingar, miljøbevisstheit og livsmeistring i vidaregåande skule: Kan 12 timar friluftsliv gjere ein skilnad? Norsk pedagogisk tidsskrift, 104(3), 226-240. https://doi.org/10.18261/issn.1504-2987-2020-03-02

Lyngstad, I., Bjerke, Ø. \& Lagestad, P. (2019). The teacher sees my absence, not my participation. Pupils experiences of being seen by the teacher in physical education. Sport, Education and Society, 24(2), 147-157. https://doi.org/10.1080/13573322.2017.1343713

Lyngstad, I. \& Sæther, E. (2020). The concept of 'friluftsliv literacy' in relation to physical literacy in physical education pedagogies. Sport, Education and Society, 26(5), 514-526. https://doi.org/10.1080/13573322.2 020.1762073 


\section{M. Tronstad $\mathcal{E}$ I. K. Lyngstad}

Malterud, K., Siersma, V. D., Guassora, A. D. (2015). Sample size in qualitative interview studies: Guided by information power. Qualitative Health Research, 26(13), 1753-1760. https://doi.org/10.1177/104973 2315617444

Maxwell, J. A. (2012). Qualitative research design: An interactive approach (3. utg.) Sage.

Michelet, S. (2020). Klassen som fellesskap: Bd. 1. Elevkultur-faglig og sosial lering. Cappelen Damm Akademisk.

Oddane, A. W. (2015). Improvisasjon - en nøkkel til rytmisk smidig beredskap overfor det uforusette. I G.-E. Torgersen (Red.), Pedagogikk for det uforusette (s. 232-262). Fagbokforlaget.

Priest, S. \& Chase, R. (1989). The conditional theory of outdoor leadershipstyle. Fournal of Adventure Education and Outdoor Leadership, 6(3), 10-17.

Priest, S. \& Gass, M. A. (1997). Effective leadership in adventure programming. Human Kinetics.

Ringer, T. M. (2002). Group action: The dynamics of groups in therapeutic, educational and corporate settings. Jessica Kingsley Publishers.

Ryen, A. (2002). Det kvalitative intervjuet. Fra vitenskapsteori til feltarbeid. Fagbokforlaget.

Schutz, W. C. (1989). The interpersonal underworld. Mill Valley.

Stensaasen, S. \& Sletta, O. (2008). Gruppeprocesser - om innlärning och samarbete i grupper. Natur och kultur.

Tjora, A. (2018). Hva er fellesskap. Universitetsforlaget.

Tordsson, B. (2014). Perspektiv på friluftslivets pedagogik (2. utg.). CVU Sønderjylland University College.

Tuckman, B. W. \& Jensen, M. A. (1977). Stages of small group development revisiteted. Group E Organization Studies, 2(4), 419-427. https://doi.org/10.1177/105960117700200404

Vikene, O. L., Vereide, V. \& Hallandsvik, L.(2016). Ledelse og læring i friluftsliv. I A. Horgen, M. L. Fasting, T. Lundhaug, L. I. Magnussen \& K. Østrem (Red.), Ute! Friluftsliv - pedagogiske, historiske og sosiologiske perspektiver (s. 107-128). Fagbokforlaget. 